\title{
Ground of Thought: Notes on Style in Some Recent Essays on American Culture
}

\author{
Texts discussed in this review: \\ Richard Poirier. Trying It Out in America: Literary and Other \\ Performances. New York: Farrar, Straus and Giroux, 1999. \\ Harold Brodkey. Sea Battles on Dry Land. New York: Metropolitan \\ Books, Henry Holt and Company, 1999. \\ Guy Davenport. The Hunter Gracchus and Other Essays on Art and \\ Literature. Washington, DC: Counterpoint, 1996.
}

In writing about style we are almost always writing about something else. An essay on style begins with the observation that "style is the man," for example, but before long the writer is chiming with Heraclitos, who wrote that "Character is fate." Style is elsewhere. In a letter to Louis Untermeyer when he was nearly 50, Robert Frost pushed at the idea and said that "style is the way [a man] carries himself toward his ideas and deeds." Read a little farther and he is into fate, calling on Emerson's visionary mode as the perfect correlation of idea and carriage. That is in the American vein, to pick not on grammar but on the clouds streaming behind the mechanics, on feeling, on tone, on the grain of the voice. Often the kicker is that style is character, another kind of fate.

So it is with Harold Brodkey. After his death it came out that he liked to slump in a chair at The New Yorker and complain. "Everyone is stealing my sentences," he is reported to have said, meaning that other writers were adopting his virtually un-copyable habit of fiddling at his own thoughts mid-sentence, rearranging the specifics of them. In that sense style is character, a way of grappling with the realities of conscious life, and doing it seriously. Frost also wrote to Untermeyer that humor was a stylistic deferral of the serious. Writing in the American grain is often something more vaporous than "consciousness" or character. The real subject is "voice," which Brodkey's sentences possess in spades, that and a wicked backspin. In any event a writer's actual sentences, whether long, drafty units or short, daggering ones has become pretty much irrelevant potatoes. 
The real arena of style lies, for most readers, in what their antennae are picking up in the sound of the word, in the way of joy, say, or desperation, or Sunday afternoons or blind alleys or bliss.

The other way is to see style as a pointer: through the sentences we can get to some separate place, a view of the world. That has been Richard Poirier's issue for decades. Poirier, professor emeritus at Rutgers University, has taken up the "world elsewhere" issue through a long and distinguished career. His latest book, Trying It Out in America: Literary and Other Performances, is an uncharacteristically scattered collection of occasional pieces and reviews written in the past decade, but anyone who knows his work will have a pretty good idea, starting anywhere, what he is up to. Dip in and read about Bette Midler in one essay, or the widely praised and (still) under-read Walt Whitman in another. There are articles on George Balanchine's genius reign at the New York City Ballet, Gore Vidal and Norman Mailer. He takes a swing at Truman Capote in another essay. And over and over he returns to the one writer he evidently admires above all others, the wild American philosopher of character, Ralph Waldo Emerson. In one essay, Poirier examines a single paragraph from Emerson's "Self-Reliance," which he regards as the most important and influential piece of writing in American literary history. Reading Poirier read Emerson, you believe it too.

But for all its range the book feels like a last offering. For a book that takes up style so much it is, thank goodness, more readable than his earlier books. No doubt many of the pieces benefited from his having to write crisper prose for publications like The New York Review of Books and The London Review of Books. Readers of Poirier's earlier books on Frost (The Work of Knowing), the American Renaissance writers (A World Elsewhere), and American Modernism (Poetry and Pragmatism) will be familiar with his usually whorled grammar and his grandly narrow preoccupations: "Nearly all the American writers I'm most concerned with here," he coughs up in his introduction, "have ambitions for themselves that are similarly in an always precarious, quite often faltering equilibrium." The subject of the sentence is - can you see? - "ambition," specifically the ambitions of the American writers of talent. But you could spend a day piecing out what he means that their ambition becomes "precarious." And "equilibrium" with what? 
Poirier, who continues in his retirement to edit the footnote-free quarterly, Raritan, which he founded in 1983, admires plain prose. Literary folks alternately love and fear his snarling marginalia on their manuscripts, and he is rumored to slash everyone else's prose mercilessly for the quarterly. But his own style is heaviosity itself, fitting grave and cryptic words like "arrangements" and "equilibrium" into paragraphs that began by wanting to explain the way a writer's voice works in poetry and prose.

And yet he is a good and careful reader. He seems to have spent time at eye- and ear-level, down among the words and the sounds of words examining the way they go together, and not mechanically but as eddies of human grunts and pauses and dartings from the subject. In this regard he has taken his cue from Frost. Get past Poirier's grizzly periods, in fact, and you are likely to learn a great deal about American literature. You may even learn to read it a whole new way. In that sense he is less a stylist than reporter on the strenuous weirdness of reading American poetry and prose, his great power as a reader discoverable in his well-deep appreciation of surface glories.

But if the sentences need work, the system does not. Poirier has an admirable lack of one. You will find no intellectual template or filter for the world of letters that makes for a broad cultural program along the lines of, for example, deconstruction. (Deconstruction always made plain old reading seem like a pitifully weak thing to spend your time on. Read a book "against the grain," as the theory demands, and the book rapidly looks hatefully full of prejudice, even when the subject is a common experience, like happiness. This can make some readers feel good about themselves but it is a bad day for happiness.) In his books Poirier prefers to maintain that writers are just saying the most interesting things in a culture, and he sticks to the local attractions, the bright phrasings that make readers of the rest of us.

Poirier is at his best flushing out certain energies and resistances in other writers' voices, the flashing "movements" of voice that hold readers on the page. For him, reading is an active appreciation of performance. So he is willing to put up with writers who may have no story to tell (Gertrude Stein) or no coherent "meaning" to convey (Frank O'Hara), but are simply lively, cool, funny, jazzy, interesting. Writing about Frank O'Hara and John Ashbery, two of the poets 
at the forefront of the New York movement in writing and art in the 1950 and 1960s, he captures the strangeness of first encountering their funny worlds of private reference, their jokes and half-stories. That they ceased to communicate much, at least in traditional terms is, he argues, something we will have to live with if we are going to follow out this American tradition of expressing the moment more or less improvisationally.

For example, Poirier makes his point vividly on a passage in O'Hara's poem, "Mayakovsky," in which the poet refers to "carrying bricks." What bricks, he wants to know? It is a passing moment in a long poem about a certain kind of witty romantic longing: a poet is writing verses while the blood pounds in his temples as he thinks of a man he wants to "just come back once / and kiss me on the face." In a middle stanza, O'Hara writes that he has blood on his chest, and realizes: "oh yes, I've been carrying bricks." Poirier notes that one commentator found the biographical note: the bricks were for a bookshelf O'Hara was building with his friend John Ashbery. As Poirier argues, the explanation is beside the point: "the passage is testimony to the peculiar nature of O'Hara's writing"; our attention "is being drawn, not to this or that particular thing, but to O'Hara's rapid movement away from it and his swift transit to something to which it bears no discernible relation at all." Later in the collection, Poirier praises Norman Mailer's habit in Ancient Evenings of consistently composing a plot that is a "getting away from something."

These are the least pat things he could write. When I was in graduate school in the cauldron of New Brunswick, New Jersey in the 1980 s, Poirier was famous for growling at anyone in class who spoke too smoothly. In that decade, when younger faculty wore black Levis and Reeboks in an effort to tie themselves visually to a lively pop culture of Terminator movies and thrash metal bands, Poirier kept up his habit of wearing expensive shoes, tailored suits, and lightly starched shirts. In seminars, he undid his tie and gazed at the ceiling as he spoke about Emerson's strange, veering habit of unsaying in one sentence what he had just said in the previous, a habit Emerson himself wrote about as an "antagonizing" feature of nature. These were curious, enigmatic things, and did not fit well with the rueful young professionals who rapped out Gallic conundrums about "power" on their new 286 computers. Poirier kept it 
simple: he grunted and pushed at his students to "read the sentence, read it." It was the most difficult thing any of us would ever do, I think.

The old guard had their greatest apologist in Poirier, who came in on the same train from New York three days a week, a copy of the New York Times under his arm. He would teach class via an old fashioned seminar style that was mostly intimidation: How be I ask you questions and you answer them? was our essential contract. Having served in World War II, he knew, as Norman Mailer knew, as a whole generation knew, the value of discipline and hard work. He didn't talk about his reading, but everybody knew that he was reading. And into his fifties and sixties he kept writing, too. He read his beloved Robert Frost in class-"Spring Pools," "Putting in the Seed"-like he was getting to the strange matter in them for the first time.

He was seriously young in the way he took in a poet like O'Hara-or Emily Dickinson and Walt Whitman for that matter. He took their brand newness seriously. Reading them it was not some larger theory about their who-ness, their "subversiveness" or identity politics he was after-highly specious claims given the way actual writers actually write-but their energy. And nothing in American life is more Pop than that.

"These poets are saying, in effect," he writes about O'Hara and Ashbery, who are the logical twentieth century children of Whitman, "that while the language available to you has to some degree already shaped and determined your experiences all day long, your use of that language in writing or reading, no matter how innovative or how much a challenge to the existing order of things, becomes still another instance of the possibility that composition flattens, deadens, or makes into a monument the very things it is meant to represent."

Let me translate: language is double-edged because it is alive in us, in our consciousness, and it is also utterly inherited and dead. Words carry with them a way of seeing the world, and we must take care to attend to their peculiarities and natural "fossil poetry" (an Emerson-ism). Otherwise, language can kill the same experiences it is meant to breathe life into. What Trying It Out stands for, at last, is Gertrude Stein's line that the primary worth of writing may not be remotely in its smooth finish or its happy endings, or what "ideas" 
it ends up with, but in the jangle of nerves and barbaric yawping that birthed it, the immediate pleasure of it, the joy of performance in it. Or as that child of Whitman, Bob Dylan, might say, literature's value lies in the ghost of electricity that howls in the bones of the work after publication.

In thinking about style, then, Poirier is more or less following writing exactly where it went in the past century-inside, into conscious life and into dreams. From Henry James to James Joyce, and from Joyce to Jorge Luis Borges and Amiri Baraka, writing spent the past 100 years following the god of the interior voice.

In American literature no more game or innovative a writer of the interior ever scribbled than Harold Brodkey. And Brodkey apparently talked in person, too. By his own account, he talked away a dozen novels that he should have written. And he took so long to publish his great novels, The Runaway Soul and Profane Friendship, that he probably lost the reputation a younger writer would have garnered. But no matter: Brodkey was a great writer, alive to voice in precisely Poirier's terms, with a comic addled quality to his voice on paper.

Here is the beginning of a chapter of Profane Friendship titled "The Movies in Venice"-Brodkey is forever a fan of the movies - whose wistful and churlish wit make for a kind of solo on the epic:

Love chiefly and the actual moments of the day are my topic, and hatred and whoring and the nature of the body and revengeful or placable memory and the wish for innocence. Also, ambition and the stages of being and the condition of the world.

I sort of sing of arms and the man, the arms of an embrace, the arms that are weapons. Not epically. Not with skill.

The dizzying whirl of "and"s and "or"s are pure offhand Americanism ("I sort of sing..."), as is the way he unmans the large enterprise of the epic tradition. And Brodkey did that in just about every piece of writing he ever published. He worries at his own voice, at his ideas too, but mostly there's a sense of him aiming at a perfect arrangement of the imperfect, dissolving world. But never portentously. If anything, he sounds like a guy who is, as he quotes 
himself saying to Carol Burnett in a piece he published in The New Yorker, "a bumbler."

That piece can be found in a posthumous collection of his essays titled Sea Battles on Dry Land. The collection is unevenly brilliant, but altogether it would be fair to call it important. And important in Poirier's modestly Frostian sense-a small miracle of fun. Here is Brodkey, for example, on the "Kaelification" of American movie reviewing. He is speaking, of course, of Pauline Kael, the longtime New Yorker film reviewer:

Ms. Kael single-handedly established the sub-elitist transitory moment as the measure, that it was always to be taken as trashy-as human - with no interest in uplift, thank God, but only in the melodramatically intense procedure of giving people what people really want. She is a very short woman and very intelligent but thoroughly unreasonable. She is masturbatorially intelligent - and successful....

But she may be the very best writer who ever lived at descriptions of the dramatic actions, of what-is-there, of what actors are doing. Her class bias and her sense of preferred subject matter-it should be grungy, raunchy, universal in that sense-are a workable recodification of the democratic common denominator....

The limited subject matter and inarticulate intelligence and nearly lunatic and often infantile opinionatedness of contemporary movies is the result.

Another writer might have regarded these paragraphs as lumber, a lot of words needing to be curbed, squared up, and settled. But the chatty thinking mode in the sentences is their stylistic genius. Does anyone really know what a "sub-elitist transitory moment" really is? Probably not, but reading the words you feel that you know.

Brodkey can be as charmingly self-involved as Holden Caulfield. One essay is the story of his attempt to figure out if Woody Allen's new movie-Husbands and Wives in 1992-is any good. He has, he confesses, to get lots of opinions before he watches a movie. Otherwise, his reactions are too eccentric. One friend tells him The Runaway Soul sits on Mia Farrow's coffee table in the film. So: "I went to the movie to see my novel make its movie debut." When he finally 
writes about the movie in the last couple of paragraphs he types up a floating scarf of thought: "Mr. Allen as a brainy, funny-looking Tony Curtis, a sweet New York guy, needs more poison in his character but he is fairly convincing as a good man." But then he gets serious and he is very good: "A good movie is not good. Or bad. It is a ground of thought, a source of named feeling, of wandering sensations, of thought about what life is and what it might be." There are few writers who could say so much with such jerry-built rapidity.

So it is instructive when Brodkey decides to take on a subject like grammar. But don't worry, it's not that instructive. "Grammar and American Reality," at five pages, is an essay less on sentences than on personal presence, and yet it would never be published in Poirier's Raritan. He fixes on the dialects at play in From Here to Eternity - not the book, the movie. (Brodkey can be almost too much fun to bear.) Montgomery Clift, he writes, is Boston and New York, and against his angst the movie rubs Sinatra and Burt Lancaster in whom there is "a lower-class background audible and visible." And Deborah Kerr uses "an acted American tone with a theatrical British English base." Donna Reed makes a "portrait of a whore as a matter of vocal inflection and facial expression and of extreme lady-likeness using school teachery English." He is interested in the marks that the actors put on the characters by a special combination of inflection and body language: on performance itself - and that is their "grammar."

One of the best essays I have ever read on the subject of American life and popular culture is Brodkey's "Translating Brando." It is supremely good, sketchy and wobbly and sure: "Part of Brando's persona as an actor is that he is a swindler and a rapist and a bully (of a certain kind), a murderer, a madman." And on Brando's eyes: "clever, androgynous, hauntingly threatening eyes, somehow also soft and weak, satyr/American-storm-trooper eyes (though they are less famous than his profile). He seems to have worn glasses at one point."

It is the casual use of the word "seems" in the last sentence, and the parenthetical "of a certain kind" in the first, that marks Brodkey as stylistically brave-brave because some of what he writes is so personal as to be the buzzing interior monologue of someone who couldn't be bothered to look "finished." Yet the excitement in his writing is just that. He swerves in the way Poirier claims Frank 
O'Hara swerves in his poems - wittily, full of light brooding, bursting with cultural knowledge but uninterested in using it against his readers. But by the end of the Brando piece it is clear that it is also autobiographical. Brodkey writes of Brando: "Brando took over the vanity and posing and sheer willfulness of a good-looking woman and developed a deconstructed version - an antiversion of a diva's romantic sexuality." According to all reports, that is Brodkey, too, making himself known via a style that points to a kind of Eden of the movie self. I am, he seems to write, because I am as alive in prose as Brando was on screen. And we are both antiversions of a diva's romantic sexuality. It is memorable because it is a snapshot of a temporary thought. It is electric because it is writing that is being thrown away.

Guy Davenport is one of the few academics who still write sentences that swing. A fiction writer, translator, essayist and MacArthur genius fellow, he is formidably learned. He has also written some of the most readable essays about American and European literature of the past several decades, including earlier collections like Geography of the Imagination and Every Force Evolves a Form, both of which were nominated for National Book Awards. He has translated Greek verse, in some cases with definitive poetic power (Sappho, Archilokos), and he has written sharply smart, if monumentally challenging fiction. He seems to have read everything twice. Like Poirier and Brodkey, but differently (he is a southerner), he is alive to the culture. But the culture that catches his eye is not theirs. A classicist by nature, he writes sentences a Shaker could admiresimple, elegantly designed, and piercingly clear. In his most recent collection of essays, The Hunter Gracchus, he takes up James Joyce (a favorite), Donald Barthelme, Gertrude Stein, Kafka (another favorite), and a score of other writers and some artists like Paul Cadmus and Grant Wood. He is a thinker in a wonderfully old fashioned sense: he writes about great writers and artists so that the average curious person will know more by the end of an essay than $\mathrm{s} /$ he did at the beginning, and he does it by working things out through a complex, but not complex-seeming bricolage.

Like Poirier, and even like Brodkey, he takes texts as his beginning. Inevitably he says what he wants by tracing nets of words as they lead back to ideas. In "Ruskin According to Proust" the subject is both a new book on Proust's translation of John Ruskin a hundred 
years ago and a fine set of ideas on the way pupils find their teachers in writing: Proust was emboldened to make an art of digression in his masterpiece thanks to Ruskin's weird, but gripping digressive style. Davenport also lets us see that in Ruskin and Proust we get to watch the fall of the city, a century ago, "as our unit of civilization."

Two pieces - chapters really - are simply great. Titled "Journal I" and "Journal II," they are carved from Davenport's own journal, and his magpie habit of thinking about the world via classical texts is a wonder: "Protagoras sold firewood," he begins Journal I. "Democritus liked the way he bundled it for carrying and hired him to be his secretary. Mind is evident in the patterns it makes. Inner, outer. To discern these patterns is to be a philosopher." His aperçus are bundled accordingly. Shortly after his epiphany about Protagoras he offers this priceless one: "The American's automobile is his body."

Regarding the bricolage habit, his title essay is instructive. Taking one of Kafka's best-known short stories, he weaves facts about the Roman family Gracchus into biographical details about Kafka. Such as? Well, that Kafka read Wilkie Collins's novel Armdale while he wrote "The Hunter Gracchus," and that it probably propelled him to go further into the idea of a "guilty past." Davenport does so not through elaborate transitions but by sections divided by titles ("A Victorian Pentimento," "De Chirico"). The sections allow Davenport to mass information so that his readers might get inside Kafka's strange story one more time, this time with a sense of where Kafka's muse carried him. The style proposes an intellectual knit: Kafka himself, as a Modernist, worked by the cut-and-paste method that we know about from reading T.S. Eliot, whereby pieces of this or that text are more or less accidentally (via the unconscious) brought together into a new thing. This also is Davenport's method.

"All messages in Kafka are incoherent, misleading, enigmatic," Davenport observes. And yet Kafka possesses a strange prescience too: "All of Kafka is about history that had not yet happened. His sister Ottla would die in the camps, along with all of his kin. The German word for insect (Ungeziefer, "vermin") that Kafka used for Gregor Samsa is the same word the Nazis used for Jews, and insect extermination was one of their obscene euphemisms.... Quite soon after the Second World War it was evident that with The Castle and The Trial, and especially with 'In the Penal Colony,' Kafka was accurately describing the mechanics of totalitarian barbarity." 
But, it should be added, in the early 1920 .

This is an interesting point. If Poirier and Brodkey finally believe, or seem to believe, in the magic of the extemporaneous, in the high vividness of the improvisational moment captured in prose, Davenport goes another direction. Writing in his spare, hard style, he says, over and over, contra Gertrude Stein, that there is a there there. Literature is not just the bump and burp of the voice. It may include improvisation, but literature, Davenport argues, may also be a tool for unraveling mysteries of history and consciousness. It is a glass and a light, an exact measurer of the immaterial, the immemorial. Reading books and studying art is a way to get to real things, and reading his essays you get the impression that the world of trash, spectatorship and wild excitement that Brodkey and Poirier like to riff on is not for him. Davenport, finally, is an American from another Emersonian tradition-not the one of "movements" and "shifts" but the one that sees religious power everywhere. This, for example, from Emerson's "Divinity School Address":

When a man comes, all books are legible, all things transparent, all religions are forms. He is religious.... All men go in flocks to this saint or that poet, avoiding [the] God who seethe in secret.

Reading Guy Davenport, especially an essay like "II Timothy," in which he writes about his own irreligious sense of the holy, we meet a maker of books, who strives to render other books legible, other things transparent.

His style, so pellucid, points, it seems, to a semi-divine elsewhere that is also practical and utterly American. 